\title{
Communication of culture through Malay quatrain
}

\begin{abstract}
The role of a language is as the tools of relationship in a society. The Malaysian societies use a lot of ways to send messages, educate, give advice, keep order and and serve many more purposes. This literary form uses comparison and idiom to achieve these ends. Every quatrain expression uses interesting and beautiful words. The aspect of the language is important while the aspect of the sound is giving aesthetics expression to the creator of the Malay quatrain. The aspect of the sound is preferred as syllables especially at the final syllables for every line. This matter is not only medium or ways of the societies is expressed, also the Malays who strongly value decency, politeness, and many more virtues. Malay quatrains state the power of high thinking and meaning and also the civilization of the Malay race. In fact since the past years, quatrain is used extensively in some social and legislative councils, trading and also in the constitutional field. Hence, this paper will discuss the role and the types of the Malay quatrain that was used to deliver the thinking and civilization. Among the classical text are the Sejarah Melayu, The Tale of Hang Tuah (Hikayat Hang Tuah), The Tale of Abdullah (Hikayat Abdullah), and The Chronicles of the Malay (Misa Melayu). The research data will be analyzed by using the sociolinguistics and pragmatic apgroaches. Besides that, this paper is also going to focus on the value of patriotism and humanity in the Malay quatrain.
\end{abstract}

Keyword: Malay Quatrain, Communication, Malay Classical Text 